\title{
Conhecimento tático-estratégico dos levantadores brasileiros campeões de voleibol: da formação ao alto nível
}

CDD. 20.ed. 796.011

796.325

\author{
Cristino J ulio Alves da Silva MATIAS* \\ Pablo J uan GRECO*
}

*Escola de Educação Física, Fisioterapia e Terapia Ocupacional, Universidade Federal de Minas Gerais.

\section{Resumo}

0 objetivo deste estudo consistiu na identificação do conhecimento tático-estratégico dos levantadores "experts", de diferentes escalões, tendo como indicativo as ações de organização ofensiva do voleibol. Da presente investigação científica participaram dezoito levantadores de ambos os sexos: campeões de São Paulo e Minas Gerais, das competições promovidas pelas Federações destes estados nos escalões Mirim (sub-14), Infantil (sub-15), Infanto (sub-17) e Juvenil (sub-20), mais um campeão Adulto (Profissional) da Superliga Masculina e Feminina. Foi aplicada uma entrevista individual e semi-estruturada com referência na grelha de conhecimento tático-estratégico do levantador (Mesouita \&t GraçA, 2002a, 2002b; Queiroga, 2005; Queiroga et al., 2010). Os textos das 18 entrevistas semi-estruturadas foram codificados, comparados e agrupados por similaridade de sentido (Duarte, 2002; Jones, 2005; Minayo \& SAnChes, 1993; Thomas \& Nelson, 2002). Entre os resultados apurados, evidenciou-se que o levantador, mesmo com condições ideais na qualidade do primeiro toque, concentra as suas ações em determinados atacantes, por não ter confiança e por limitações táticas e técnicas dos outros jogadores em suas ações ofensivas finais. Além disto, os resultados indicam que os levantadores estão em constante evolução, independente dos anos de prática no voleibol, com referências de todos eles quanto à importância do treino como uma fonte de conhecimento, dentre outras.

UnITERMOS: Cognição e ação; Levantador; Distribuição; Voleibol.

\section{Introdução}

Nos Jogos Esportivos Coletivos é importante a captação da informação do ambiente de jogo para se concretizar a tomada de decisão. Na situação de jogo é preciso agir de modo contrário a previsibilidade ou se adaptar a imprevisibilidade do jogo. É necessário que o atleta tenha o conhecimento da sua modalidade esportiva para solucionar os problemas presentes no contexto do jogo. Os processos cognitivos contribuem nessa resolução a qual será efetivada via a execução de uma habilidade motora (ALves, 2004; GARGANTA, 2000, 2004, 2006; GreCO, 2006a, 2006b; Matias \& Greco, 2010; MCMorris, 1999; Mesquita, 2005).

O comportamento tático-estratégico do jogador solicita relacionar a recepção de informação com o conhecimento para elaboração da resposta à situação (GARGANTA, 2006). Portanto, no esporte coletivo a ação sempre tem finalidade tático-estratégica (ALVES, 2004; GARGANTA, 2006). Considera-se tática como o uso de um sistema de planos de ação e de alternativas de decisão que permitem regular a atividade fazendo com que seja possível o êxito esportivo (HaGEDORN, 2003).

Garganta e Oliveira (1996) sustentam que não se diferencia estratégia e tática, sendo que as duas possuem a mesma estrutura cognitiva e o mesmo foco situacional que se funde no ato motor do jogador. Salientar isto é necessário devido às classificaçōes que descrevem estratégia como preparação das tomadas decisórias antes do jogo, decisões elaboradas principalmente por parte do treinador; enquanto tática em referência às decisões efetuadas no transcorrer da partida pelo jogador, fruto ou não de adaptações provenientes da estratégia elaborada. Desde modo, é solicitada uma constante atitude tático-estratégica aos jogadores. Tal atitude se efetua mediante comportamentos observáveis no decorrer do jogo, cuja qualidade depende do conhecimento que o próprio jogador tem sobre a modalidade esportiva em particular (Alves, 2004; GARGANTA, 2000, 2004, 2006). 
Dentre os conhecimentos necessários aos jogadores, referentes aos diversos Jogos Esportivos Coletivos, distinguem-se dois tipos: o declarativo e o processual (Allard, 1993; Allard \& Burnett, 1985; Thomas, French \& Humphries, 1986; TurNER \& MARTINEK, 1995). O declarativo faz menção à capacidade do jogador de saber "o que fazer", isto é, conseguir declarar de forma verbal e/ou escrita qual a melhor decisão a ser tomada e o porquê desta decisão. O processual faz menção a "como fazer", é a capacidade do atleta de operacionalizar a ação, é intimamente ligado a ação motora em si, automatizado, aparentemente sem recordação consciente (Anderson, 1983, 1995; Giacomini \& Greco, 2008; HenKe, 2010; Matias \& Greco, 2010; STERNBERG, 2008; VILHENA \& GRECO, 2009). Ressalta-se que estes conhecimentos, declarativo e processual, se relacionam e são utilizados pelos jogadores na solução das tarefas e/ou dos problemas com que se defrontam no jogo (GRECO, 2006a, 2006b).

Quando se indaga quais são as características dos jogadores peritos, as respostas dos treinadores direcionam-se aos processos cognitivos. As colocações dos mesmos são: os jogadores "lêem" bem as situaçōes de jogo; adaptam-se ao jogo, mas também se "impõem"; as ações são de fácil execução e sem esforço aparente; as decisões frequentemente resultam em sucesso para a equipe (ARAújo \& Volossovitch, 2005). Assim sendo, as características dos peritos em relação aos novatos podem ser sintetizadas pelo conhecimento organizado e estruturado das probabilidades de ocorrência situacional (conhecimento declarativo e processual), que levam a uma maior objetividade nos processos de procura visual; de busca e acesso de informação especifica no reconhecimento de padrões e assim uma rápida e eficiente seleção de sinais relevantes. Os peritos aproveitam melhor o significado desses sinais, possibilitando rapidez e tempo para ter precisão na tomada de decisão. Também se caracterizam por apresentar uma maior capacidade de planejar as ações antecipadamente, o que os leva a uma auto-regulação-tática permitindo uma maior capacidade de adaptação a situações novas (BANKS \& MillWARD, 2007; FRENCH \& MCPHERSON, 1999; French, Nevet, Spurgeon, Graham, Rink \& McPherson, 1996; Mann, Williams, Ward \& JANElle, 2007; MCPherson, 1994; MCPherson \& Kernodle, 2007; Quintana, Roman, Calvo \& Molinuevo, 2007; Rink, French \& TJeerdsma, 1996; Tenenbaum, 2003; Williams, 2002a, 2002b).

No contexto dos Jogos Esportivos Coletivos a ação tática solicita a tomada de decisão do jogador. Neste processo decisório há uma sequência de aspectos que apresentam situações de pressão de tempo, de precisão, de carga, entre outras formas de pressão (KRÖGER $\&$ Rотн, 2002). A ação tática é desencadeada com o intuito de ganhar ou manter a vantagem sobre os adversários. Em todo momento tem-se como referência para elaboração da ação tática a inter-relação da triologia "espaço-tempo-situação" (GARGANTA, 2006; Greco \& Benda, 1998; Matias \& Greco, 2010). Constrói-se, portanto, uma estreita relação de dependência recíproca entre tática e processos cognitivos (Greco, 1995). Dentro deste contexto, o praticante detecta as informações, os sinais relevantes, que expõem possibilidades de sucesso para a sua tomada de decisão (GARGANTA, 2004; LAGUNA, 2005), da qual poderá emergir uma ação inteligente e/ou criativa (GRECO, 2006a, 2006b).

Entre as modalidades dos Jogos Esportivos Coletivos, o voleibol tem no levantador o jogador nuclear no desenvolvimento tático-estratégico ofensivo do jogo e por isto é considerado o "cérebro" da equipe (Matias \& Greco, 2009; Palao, Santos \& UREÑA, 2004, 2005; ReZENDE, 1995). O levantador, dentre todos os atletas de uma equipe, é o que tem de processar uma maior quantidade e variedade de informação, além de tomar as mais críticas decisões ofensivas (MESQUiTA \& GRAÇA, 2002a, 2002b).

Com a própria evolução do voleibol, o levantador passou a ter um diferente significado tático-estratégico para o jogo. Já não é mais suficiente apenas erguer uma bola alta para o atacante. Hoje o levantador deve organizar todo o sistema de ataque: decidir em utilizar dois, três ou quatro atacantes, definir o percurso de movimentação destes jogadores, a velocidade do deslocamento de cada um destes atacantes, observar o posicionamento do bloqueio e até mesmo o posicionamento defensivo adversário. Nesta coordenação ofensiva o levantador jamais deverá negligenciar a precisão das próprias açōes (MATIAS \& GRECO, 2009; Mesquita \& GraÇA, 2002a, 2002b; QueIroga, MAtias, Mesquita \& Greco, 2010; Resende, 1995).

O levantador não efetua um simples passe, acima da linha de rede, para um atacante. A sua ação no voleibol moderno consiste na distribuição de jogo com início no saque adversário ou logo após o término de uma jogada adversária. Nestes momentos se pré-determina o deslocamento de cada um dos atacantes. O fim é no ato da escolha de uma das opçóes pré-determinadas ou modificadas em decorrência da qualidade da recepção e/ou defesa, onde se apura por meio da execução do ataque o efeito final da sua decisão (Serenini, Freire \& Noce, 1998; Ramos, 
Nascimento, Donega, Novaes, Souza, Silva \& Lopes, 2004; Matias \& Greco, 2009; Marcelino, Mesquita, Sampaio \& Moraes, 2010). Deste modo, o levantador pode ser denominado de distribuidor, pois deve determinar toda movimentação ofensiva da sua equipe, otimizar a qualidade do primeiro toque e optar por um dos jogadores da sua equipe para ser o responsável pela execução do ataque (MAtias \& Greco, 2009; Mesquita \& Graça, 2002a, 2002b; Palao, Santos \& Ureña, 2004).

Dentro deste contexto torna-se pertinente realizar estudos que se centrem nas representaçôes de jogadores "experts", mormente no conhecimento tático-estratégico verbalizado em relação às ações táticas do levantador, em situação real de jogo, como se pretende no presente estudo. Acrescenta-se a isto o fato deste estudo ser realizado com indivíduos de diferentes faixas etárias e de ambos os sexos. Assim, há uma maior compreensão da tomada de decisão no decurso das diferentes faixas etárias.

\section{Métodos}

\section{Cuidados éticos}

$\mathrm{Na}$ realização deste estudo foram respeitadas as normas estabelecidas pelo Conselho Nacional em Saúde, sobre pesquisas envolvendo seres humanos, sendo aprovado pelo Comitê de Ética em Pesquisa da Universidade Federal de Minas Gerais: parecer no ETIC 165/08.

\section{Caracterização do estudo}

Este estudo caracteriza-se como um tipo de pesquisa aplicada. Tipo de pesquisa que tem valor imediato para os profissionais do esporte, pois surge da necessidade de entender questóes relevantes em contextos não laboratoriais. É uma pesquisa que se desenvolve nos ambientes reais de ação dos indivíduos, constituída de uma alta validade ecológica (Kellmann \& Beckmann, 2003; Thomas, Nelson $\&$ Silverman, 2005).

O presente estudo fez uso da abordagem qualitativa, desde modo, busca compreender o significado de uma experiência exclusiva dos participantes, em um ambiente específico. Além disso, busca-se compreender como os componentes se mesclam para formar o todo (CORTES, 1998; Jones, 2005; Minayo \& SANCHES, 1993).
Ressalta-se a carência de estudos desta natureza. A maioria das investigações em Ciências do Esporte é efetuada com indivíduos da mesma faixa etária e sexo, não sendo tão possível compreender como a decisão se comporta ao longo dos escalōes (Costa, Garganta, Fonseca \& Botelho, 2002; Giacomini, 2007; Milistetd, Mesquita, Nascimento \& Sousa Sobrinho, 2010). Além disto, investigações sistemáticas sobre aspectos específicos do Voleibol Brasileiro são relevantes. Isto, pois, o Brasil possui inúmeras conquistas de relevância internacional, sendo o Voleibol Brasileiro na atualidade uma referencial inegável no alto nível de rendimento à escala mundial (MilisteTd et al., 2010).

Com base no contexto abordado anteriormente, o objetivo do presente trabalho consiste em investigar o conhecimento tático-estratégico, dos levantadores de alto nível do voleibol brasileiro, de distintos escalóes de competição, tendo como indicativo as suas ações de distribuição de jogo.

\section{Participantes}

O número de indivíduos participantes deste estudo foi determinado pela amostragem não probabilística, dentro desta classificação foi empregada a amostragem por julgamento: seleção de indivíduos a critério do pesquisador (LUNA, 1998). O critério aplicado aos levantadores de Minas Gerais (MG) e São Paulo (SP), definia que somente o levantador titular da equipe campeã, de cada um dos campeonatos das Federações de Voleibol destes Estados, do Mirim ao Juvenil (base), feminino e masculino, estava eleito para participar desta pesquisa.

O critério aplicado foi em decorrência dos inúmeros títulos conquistados por estes Estados, nas competições nacionais de base, promovidas pela Confederação Brasileira de Voleibol (CBV). Foi incluído também o levantador titular da equipe campeã da Superliga, de ambos os sexos, organizado pela CBV (Maroni, Mendes \& Bastos, 2010; RAMOs et al., 2004).

Ocorreu a substituição de um levantador campeão estadual do Estado MG e outro de SP. Estes foram substituídos pelo campeão Metropolitano de SP e pelo campeão do Campeonato Brasileiro de Seleções Estaduais (Divisão Especial - organização CBV), de acordo com o respectivo escalão. Isto, com o intuito 
de se manter preservado o sigilo da identidade dos voluntários. Pela representatividade, os levantadores desta amostra são considerados como de alto nível (experts) em cada um dos escalóes de competição no voleibol. Participaram do estudo 18 levantadores: dois levantadores de cada sexo nos escalóes Mirim, Infantil, Infanto e Juvenil e no escalão Adulto (Superliga) um levantador de cada sexo.

\section{Caracterização da amostra}

Na TABELA 1 observam-se os dados descritivos desta amostra, com a média $(\bar{\chi})$ e o desvio padrão (DP) da Idade, do Tempo de Prática de Voleibol e do Tempo de Prática como Levantador de Voleibol. A amostra teve a mesma média de Idade, nos dois sexos, do escalão Mirim ao Infanto, com exceção do escaláo Juvenil. Ao se observar o Tempo de Prática de Voleibol e o Tempo de Prática como Levantador percebe-se que, em todos os escalōes, a especialização na posição de levantador começou após o jogador já estar inserido no processo de ensino-aprendizagemtreinamento do voleibol, seja por meio da prática inicial do voleibol no sistema de jogo 6x6 [sistema sem função especifica para os jogadores, todos atacam e levantam (BızzOcCHI, 2000)] e/ou por já ter atuado anteriormente como atacante. Nota-se um tempo similar de prática como levantador de voleibol do Mirim ao Juvenil, em ambos os sexos. Verifica-se um maior Tempo de Prática como Levantador no escalão Adulto, em relação a todos os demais, seja no masculino ou no feminino.

TABELA 1- Caracterização da amostra: estatística descritiva da variável idade, tempo de prática de voleibol e tempo de prática como levantador.

\begin{tabular}{llccccccc}
\hline \multicolumn{2}{c}{ Sexo/Escaláo } & $\mathbf{n}$ & $\begin{array}{c}\bar{\chi} \\
\text { *Idade }\end{array}$ & DP & $\begin{array}{c}\bar{\chi} \\
\text { *Tempo de prática } \\
\text { de voleibol }\end{array}$ & DP & $\begin{array}{c}\bar{\chi} \\
\text { *Tempo de prática } \\
\text { como levantador }\end{array}$ & DP \\
\hline Feminino & Mirim & 2 & 14 & 0,00 & 6 & 1,41 & 4 & 0,00 \\
& Infantil & 2 & 15 & 0,00 & 7 & 2,82 & 3 & 0,70 \\
& Infanto & 2 & 17 & 0,00 & 9 & 1,41 & 5 & 2,82 \\
& Juvenil & 2 & 17 & 0,00 & 8 & 2,12 & 4,5 & 2,12 \\
& Adulto & 1 & 38 & - & 29 & - & 19 & - \\
Masculino & Mirim & 2 & 14 & 0,00 & 5 & 0,00 & 4 & 0,00 \\
& Infantil & 2 & 15 & 0,00 & 5 & 0,00 & 4,5 & 0,70 \\
& Infanto & 2 & 17 & 0,00 & 5 & 3,53 & 4,5 & 3,53 \\
& Juvenil & 2 & 18 & 1,41 & 6 & 2,82 & 3 & 1,41 \\
& Adulto & 1 & 32 & - & 22 & - & 15 & - \\
\hline
\end{tabular}

\section{Instrumento}

Para avaliar o conhecimento tático-estratégico dos levantadores foi usada a entrevista semi-estruturada baseada no estudo de Mesquita e GraÇA (2002a, 2002b), Queiroga (2005) e Queiroga et al., (2010). A entrevista semi-estruturada englobou 18 questões de resposta aberta (QUADRO 1). O procedimento adotado, na realização destas perguntas da entrevista semi-estruturada, seguiu as orientações de Minayo e Minayo (1999) e Thomas e Nelson (2002). Assim, a ordem das perguntas para todos os levantadores não teve uma sequência rígida, tendo ocorrido alteração sempre que foi construída uma resposta com ênfase e associação em uma indagação de uma pergunta que não era a subsequente. Perguntas não inseridas, na entrevista semi-estruturada, formularam-se quando as respostas dos atletas exigiram um esclarecimento ou aprofundamento. 
QUADRO1-Entrevista semi-estruturada com o levantador de voleibol.

\begin{tabular}{|c|c|}
\hline 1. & Qual é o papel do levantador no jogo de Voleibol? \\
\hline 2. & Quais são para si os requisitos essenciais para ser um levantador de alto nível? \\
\hline 3. & Em sua opinião qual é a característica mais importante do levantador? \\
\hline 4. & O que distingue um levantador excepcional de um bom levantador? \\
\hline 5. & Ser levantador implica ser líder da equipe? \\
\hline 6. & Você pensa e elabora estratégias antes do jogo? \\
\hline 7. & As opções do levantador no jogo são sempre em referências as quais aspectos? \\
\hline 8. & O resultado do jogo tem influência nas decisóes que toma (ganhando, perdendo ou estando equilibrado o jogo)? \\
\hline 9. & O momento do set condiciona as suas opções (início, meio ou fim)? \\
\hline 10. & O fato de "determinados" jogadores estarem em determinada zona condiciona as suas opçôes? \\
\hline 11. & Você se preocupa em relação aos bloqueadores adversários, sobre o que eles estão a pensar no quê você vai fazer? \\
\hline 12. & O tipo de passe que efetua é em função da zona em que quer o atacante bata? Faz isso com todos os atacantes? \\
\hline 13. & Quando o atacante não foi eficiente o que você faz? \\
\hline 14. & Quais são as características que um jogador deve ter para ser o seu atacante de confiança? \\
\hline 15. & No momento em que um atacante é bloqueado o que você pensa? \\
\hline 16. & $\begin{array}{l}\text { Quando você deixa um atacante em condição favorável (em situação de oposição com um bloqueio ou sem } \\
\text { nenhum bloqueio) e ele erra o ataque, qual é a sua reação perante a ele, perante você e perante a situação? }\end{array}$ \\
\hline 17. & Como você reage perante um erro, no levantamento, de condução ou de dois toques? \\
\hline 18. & Como você procura agir no pedido de tempo técnico? \\
\hline
\end{tabular}

\section{Coleta de dados}

A coleta de dados com os levantadores que se sagraram campeões foi agendada através de um contato telefônico com o diretor, o supervisor e o treinador da instituição, mais os pais/ou responsáveis pelos levantadores menores de idade e em seguida com o próprio levantador. No encontro pessoal, na instituição que o levantador treina e representa, o diretor, o supervisor, o treinador, os responsáveis pelo levantador e o próprio levantador foram informados a respeito da pesquisa, da concordância do clube, do direito a participação voluntária e do direito de desistência sem a ocorrência de prejuízo e constrangimento aos mesmos. Ao fim destes esclarecimentos foram assinados os termos: Concordância da Instituição e Consentimento Livre e Esclarecido.

A coleta de dados foi efetuada no local de treinamento de cada um dos levantadores, antes ou após o treino. As respostas dadas pelos atletas, decorrentes da sua identificação, da sua experiência na prática esportiva e da entrevista semi-estrutura foram registradas no gravador digital da Panasonic, modelo RR-US430. A coleta de dados com cada um dos levantadores teve a duração aproximada de 40 minutos e realizou-se sempre em uma sala silenciosa, com a presença apenas do pesquisador e do levantador.

\section{Análise dos dados}

As entrevistas semi-estruturadas foram transcritas integralmente, para o "software" Word 2007 da Microsoft, pelo pesquisador responsável por este trabalho (com uma experiência superior de 10 anos como treinador de voleibol de base e alto nível) e por mais dois alunos do curso de graduação em Educação Física da UFMG, que foram atletas participantes dos campeonatos de base da Federação Mineira de Voleibol e da CBV.

Para assegurar a autenticidade e veracidade do conteúdo das entrevistas, estas foram enviadas aos levantadores, para que fossem lidas as transcrições e o uso nesta pesquisa autorizado. O conteúdo das 18 entrevistas semi-estruturadas foi liberado por cada um dos levantadores.

Os textos das entrevistas semi-estruturadas foram codificados, comparados e agrupados por similaridade de sentido (DUARTE, 2002; JONES, 2005; Minayo \& Sanches, 1993; Thomas \& Nelson, 2002), mediante a Análise de Conteúdo, por intermédio da análise categorial (CAMPOS, 2004; Caregnato \& Mutti, 2006; Rocha \& Deusdará, 2005). Para os recortes de textos e as respectivas formações das categorias foi empregado como referencial as categorias presentes nas 
dimensões da grelha de Conhecimento TáticoEstratégico do Levantador de Voleibol (QUADRO 2): Características Pessoais, Virtuosismo do Jogador, Fontes de Conhecimento e Indicadores de Jogo para Tomada de Decisão Tática (MESQUiTA \& Graça, 2002a, 2002b; Queiroga, 2005; Queiroga, Matias, Greco, Graça \& Mesquita, 2005; Queiroga et al., 2010). Deste modo, a validade de construção foi assegurada (PASQUALI, 2004, 2007).
Depois de formadas as categorias, dois treinadores da Superliga conferiram se as categorias codificadas, a partir da entrevista semi-estruturada, possuíam similaridade de sentido ao ser agrupada com a respectiva parte do texto transcrito. Os treinadores confrontados com a codificação original, em momentos distintos, concordaram integramente com os recortes nas transcriçôes e as respectivas categorias. De tal forma, por meio do consenso, foi garantida a validade de conteúdo (PASQUALI, 2004, 2007).

QUADRO 2 -Grelha acerca do conhecimento tático-estratégico do levantador de voleibol (adaptada de MESQUITA \& Graça, 2002a, 2002b; Queiroga, 2005; Queiroga et al., 2005, 2010).

\begin{tabular}{|c|c|}
\hline Características Pessoais & Virtuosismo do Jogador \\
\hline Liderança & Estrategista \\
\hline Gestor da Equipe & Gestor de Riscos \\
\hline Psicólogo da Equipe & Contra-Comunicador \\
\hline Racionalidade & Plasticidade Técnica \\
\hline Confiança & Visão de Jogo \\
\hline Intuição & Velocidade \\
\hline Cobrança & \\
\hline \multicolumn{2}{|c|}{ Fontes de Conhecimento } \\
\hline \multicolumn{2}{|c|}{ Treino } \\
\hline \multicolumn{2}{|c|}{ Observação de Jogo } \\
\hline \multicolumn{2}{|c|}{ Observação de Levantadores mais Experientes } \\
\hline \multicolumn{2}{|c|}{ Diálogo com o Treinador } \\
\hline \multicolumn{2}{|c|}{ Experiência Refletida } \\
\hline \multicolumn{2}{|c|}{ Indicadores de Jogo para Tomada de Decisão Tática } \\
\hline \multicolumn{2}{|c|}{ Características das Equipes } \\
\hline \multicolumn{2}{|c|}{ Características Técnicas e Táticas dos Nossos Atacantes } \\
\hline \multicolumn{2}{|c|}{ Melhor Atacante e Momento do Jogo } \\
\hline \multicolumn{2}{|c|}{ Características Psicológicas dos Nossos Atacantes } \\
\hline \multicolumn{2}{|c|}{ Qualidade do Primeiro Toque } \\
\hline \multicolumn{2}{|c|}{ Bloqueio Adversário } \\
\hline \multicolumn{2}{|c|}{ Fluxo de Jogo } \\
\hline \multicolumn{2}{|c|}{ Mudar para Prevenir a Adaptação do Adversário } \\
\hline \multicolumn{2}{|c|}{ Jogar em Relação ao Bloqueio Adversário } \\
\hline \multicolumn{2}{|c|}{ Adaptar a Técnica de Levantamento e a Direção do Movimento } \\
\hline \multicolumn{2}{|c|}{ Situaçōes Imprevistas } \\
\hline
\end{tabular}

Houve concordância plena entre as transcrições realizadas, para garantir a fiabilidade das mesmas, mediante audição e confirmação de pequenos segmentos do texto (de palavras, expressóes e pequenas frases).

O exame dos dados qualitativos do presente trabalho, fruto da entrevista semi-estruturada, seguiu as orientaçōes de triangulação propostas para a confiabiliade na pesquisa qualitativa (JONES, 2005; THOMAS \& NelSON 2002): verificação das transcriçōes por outros indivíduos com conhecimento da modalidade esportiva, voleibol, mais a conferência das transcrições efetuada pelos próprios entrevistados. 


\section{Resultados e discussão}

A Análise de Conteúdo, por meio da análise categorial, possibilitou a construção das categorias em comum com a grelha de Conhecimento TáticoEstratégico do Levantador de Voleibol e permitiu também a identificação de novas categorias.

Logo abaixo são expostas estas categorias. Nesta exposição o escalão Adulto possui recortes textuais descritos em todas as categorias, alusivos a fala de um dos sexos. Além disto, dos escalóes de base são apresentados um ou mais recortes. Assim, por categoria é apresentado, na maior parte dos resultados, no mínimo três recortes, dois referentes aos escalóes de base e um referente ao escalão Adulto. O teor de cada uma das categorias é discutido em suas respectivas dimensões.

\section{Dimensão: características pessoais}

\section{Liderança}

A liderança pode ser compreendida como exercício de influência, como a forma de um indivíduo induzir outros a se comportar de forma desejada, como a preocupação entre as relações de trabalho e bem estar do grupo (Noce, 2002). Ficou demonstrado que o levantador deve ser o líder da equipe pelo fato da sua participação direta em toda construção ofensiva, independente de ser o capitão ou não capitão da equipe.

... não necessariamente ser o capitão, mas líder dentro da equipe eu acho que tem que ser sim, tanto nos treinos, quanto nos jogos. Mirim Feminino $^{1}$

Eu acho que tem que ser líder porque ele que vai mandar no jogo, o levantador que vai fazer a distribuição, então ele tem que ter os atacantes na mão dele, então ele tem que pedir o passe do modo que ele quer e todos terão que compreender o que ele quer e deverão seguir as ordens. Se o levantador não tiver liderança fica muito difícil para uma equipe vencer jogos e principalmente um campeonato. Infanto Masculino $^{2}$

A maioria dos levantadores são os capitães das equipes, hoje e como sempre foi, o levantador é a imagem do treinador dentro da quadra. Por eu ser o levantador (o líder na quadra) tenho que cobrar. Adulto Masculino

\section{Gestor de equipe}

A gestão pode ser compreendida como planejamento, organização, direção e liderança que o gestor exerce para atingir objetivos apoiados em previsões, cálculos e planos (Maroni, Mendes \& Bastos, 2010; Moreira \& Freitas, 2009; SuAidEn, Barros \& AzEvÊdo 2004). Ficou demonstrado a necessidade do levantador ser gestor da equipe, em relação à organização ofensiva da equipe, pelo fato da sua ação no jogo de jogo estar interligada com o antes e o depois do levantamento, assim o levantador deve se comunicar com o intuito de planejar, organizar e controlar o passe e o ataque dos demais jogadores em quadra, isto tendo como referência a eficácia no jogo e aspectos psicológicos [estado de ânimo, disposição de esforço, autoconfiança e nível de aspiração (SAMULSKI, 2002)].

... depois eu falo, corrijo, vejo com os atacantes se a bola está baixa. Pergunto como está o meu levantamento, para poder melhorar a relação levantador/atacante e trazendo assim o atacante para o jogo. Mirim Masculino

... não tem muito essa de que eu tenho que colocar bola na atacante porque ela pediu, ou todo mundo tem que estar recebendo bola para atacar, nada disto. Depende do jogo, tem jogo que dá para colocar bola, tipo jogos mais fáceis, então você pode colocar todo mundo para jogar, para treinar os ataques. No jogo importante tem os momentos certos, não pode ir colocando bola para todo mundo, eu é que decido o momento certo. Infantil Feminino ${ }^{2}$

... a coordenação do jogo é obrigação do levantador, ele deve conhecer o potencial e a limitação de cada jogador, seja no passe, no ataque, no bloqueio, então, o levantador tem que possuir o controle tático e psicológico do jogo.” Adulto Feminino

\section{Psicólogo da equipe}

Ser psicólogo da equipe deve ser compreendido como o conhecimento que o atleta deve possuir do comportamento dos jogadores da sua equipe, para poder motivar, promover a coesão do grupo, estabelecer metas, manter uma atitude positiva na equipe e elevar a moral daqueles que não estão bem (QUEIROGA, 2004). Os levantadores do presente estudo citam que em sua função de jogo é necessário o conhecimento do comportamento dos jogadores da 
equipe para saber lidar e tirar o rendimento positivo de cada um, dentro dos diferentes contextos de jogo. ... você tem que saber controlar as jogadoras em quadra, tem que saber como cada jogadora se comporta e ajudá-la, seja deixando ela mais calma ou mais motivada. Infanto Feminino ${ }^{2}$

... não sou uma pessoa que brigue com os jogadores em quadra, procuro sempre motivar os meus companheiros em quadra para que possa ter confiança neles, procuro saber como cada um é para poder saber como falar com cada um. Juvenil Feminino ${ }^{2}$

... o levantador sempre deve estar muito motivado e alegre em quadra, pois isto contamina o time, deve vibrar a cada ponto, sem perder o foco do jogo. $\mathrm{O}$ levantador é o termômetro do time, ele tem que sentir como está cada jogador psicologicamente no jogo e deve procurar conversar com cada jogador dentro das particularidades de cada um. Se for preciso, além de conversar, tirar um pouco as bolas do atacante e indo recuperando ele, deixando ele motivado e confiante para voltar a atacar. Às vezes é melhor até dar bola para ele atacar para que ele se recupere mais rápido para o jogo, por exemplo, após levar um toco. Adulto Masculino

\section{Racionalidade}

A racionalidade pode ser compreendida como mecanismo pelo qual um sujeito tenta explicar seus comportamentos ou seus sentimentos baseados nas regras da lógica ou da ideologia em vigor (DORON $\&$ Parot, 2002). De acordo com Samulski, Noce e CHAGAS (2002) existe uma relação entre ativação fisiológica, ansiedade e performance. Cada atleta possui uma zona ótima de ativação e ansiedade que é o ideal para o seu rendimento, esta zona de alta performance é peculiar a cada indivíduo e pode ocorrer com um baixo, médio ou alto nível de ativação e ansiedade. Caso haja uma queda do rendimento no transcorrer de uma partida, os atletas devem se reestruturar cognitivamente por meio da eliminação e controle das preocupações e, finalmente, reativar-se e motivar-se novamente de forma controlada. Segundo Queiroga (2005) o levantador deve possuir controle das próprias emoçôes durante o jogo, sobretudo nos momentos decisivos, pois a falta da regulação das emoções poderá interferir na sua tomada de decisão. Ficou demonstrado a necessidade do levantador não deixar que suas ações de jogo sejam influenciadas por suas emoções negativas, decorrentes do próprio erro do levantador ou dos erros cometidos pelos atacantes. Geralmente não funciona inventar uma jogada na hora do jogo, sai errado. Tem que fazer o que é treinado no dia a dia, sem se desesperar com um bloqueio ou com um erro em uma bola fácil que alguém cometeu, inclusive eu, eu não posso ficar com raiva se cometi algum erro, se não irei me perder no jogo. Mirim Masculino ${ }^{1}$

O levantador não pode provocar o erro do atacante para tirá-lo do jogo, nunca pode criar uma situação para substituir um atacante por outro do banco. O levantador tem é que armar situaçōes para os atacantes poderem virar a bola. Infanto Feminino ${ }^{1}$

... o levantador não pode se abalar com erro em quadra, a melhor coisa é acertar a próxima bola e conduzir a equipe com tranquilidade em cada uma das decisōes de levantamento. Adulto Feminino

\section{Confiança}

A confiança pode ser compreendida como condiçãao fundamental entre os atletas de uma equipe na obtenção da vitória, bem como a confiança nos membros da comissão técnica (CORRÊA, 2004). Ficou demonstrado a utilização dos atacantes por parte do levantador até mesmo em momentos difíceis para o ataque, situaçóes com bloqueio duplo, isto devido à confiança que o levantador possui no atacante. Esta confiança diminui a importância da percepção do bloqueio na tomada de decisão do levantador. A confiança é construída nos treinos e jogos a partir da eficácia do atacante. O levantamento nos momentos decisivos de um jogo é baseado na relação de confiança entre o levantador e o atacante. ... eu tenho confiança nas minhas atacantes, independente do bloqueio ou não elas vão virar a bola. Mirim Feminino ${ }^{1}$

... se for atacante de confiança você coloca depois de um bloqueio, pois se é de confiança é porque ele já virou muita bola das mais diversas maneiras, isto é que gera a confiança do levantador no atacante. Infanto Feminino ${ }^{2}$

... a confiança se constrói sempre que se está presente com o atleta, nos treinos, descansos e na hora do jogo. Sempre que escolho um atacante é porque confio nele, então nos momentos de pressão procuro ver qual jogador está realmente confiante em si próprio. Adulto Feminino 


\section{Intuição}

A intuição utiliza como base a experiência e os conhecimentos prévios, a reflexão e a análise são necessárias para melhorar a intuição e como consequência a adaptação ao jogo (LAGUNA, 2005; MATIAS \& GRECO, 2010). Fica clara a referência da Intuição, no presente estudo, através da tomada de decisão efetuada pelos levantadores no último instante das suas açôes, alterando uma decisão que já estava préestabelecida com base em sinais relevantes, qualidade do primeiro toque e formação de bloqueio.

... vai de instinto, tive jogos apertados, pau a pau, ai arrisquei uma bola em um atacante de meio, um atacante que talvez não fosse virar, tive a intuição de colocar a bola para ele e coloquei, mas nem sempre faço isto. Mirim Masculino ${ }^{1}$

... o jogador tem que ter o 'feeling' do jogo, sentir o jogo ali rapidamente para decidir. Infanto Feminino $^{2}$

... às vezes está tudo programado já na sua mente para fazer, o passe saiu, você percebeu o bloqueio, mas por intuição você muda o atacante que iria receber a bola. Adulto Feminino

\section{Cobrança}

$\mathrm{O}$ ato de cobrar os colegas de equipe objetiva a conquista da vitória, portanto todos os integrantes da equipe devem saber de seus deveres, direitos e responsabilidades, dentro das suas possibilidades e das suas funçōes no jogo (QueIroga, 2005; QueIroga et al., 2010). Ficou demonstrada a cobrança do levantador para com o atacante em situaçóes de erro de ataque contra bloqueio simples ou sem bloqueio, tendo em menor grau uma cobrança com os jogadores que executam a recepção do saque com baixa qualidade. ... às vezes é uma jogada complicada de faze, e consigo fazer, e o atacante erra, acaba fazendo o mais difícil, que é errar. Pode acontecer de errar, depende da situação, pode ser que a pessoa errou por mérito do bloqueio, marcou uma zona, jogou o braço e conseguiu bloquear. Mas pode ser também porque a pessoa chegou atrasada na bola e deixou a bola cai e deu para baixo no ataque. Eu cobro muito se $o$ atacante errou por desleixo. Infanto Masculino ${ }^{1}$

... se eu faço uma jogada com bloqueio simples ou sem bloqueio e o atacante não roda eu vou até ele e dou um esporro, mas não para humilhar o cara, mas para que ele saiba que confio nele e ele não pode cometer estes tipos de erro. Juvenil Masculino ${ }^{1}$

... eu não brigo muito com as passadoras quando elas erram, eu deixo a responsabilidade comigo e não com as meninas do passe. Se a bola chegar ruim eu deixo comigo e não com as meninas do passe. Juvenil Feminino ${ }^{1}$

... o único momento em que fico brava é quando esquematizo toda a jogada e consigo colocar o atacante contra bloqueio simples. Com bloqueio simples o atacante deve colocar a bola no chão, então fico chateada, pois é uma jogada que deveria terminar em ponto, é um momento que fico brava e cobro do atacante. Adulto Feminino

\section{Dimensão: virtuosismo do jogador}

\section{Estrategista}

As estratégias individuais e coletivas condicionam as decisóes com o intuito de vencer o jogo a partir das características físicas, psicológicas, técnicas e táticas observadas na própria equipe e no adversário (Garganta \& Gréhaigne, 1999; Matias \& GreCO, 2009; Platonov 2008). Ficou demonstrada a estratégia do levantador na adaptação do plano de jogo e das suas tomadas de decisões em referência ao adversário, ao momento do jogo, a velocidade da distribuição e a eficácia dos próprios atacantes.

$\mathrm{Eu}$ acho que a diferença no nosso título de campeão foi que todas as equipes tinham um levantador bom e um atacante que virava. Eu na minha equipe tinha dois atacantes muito bons, eu focava o jogo nos meus dois atacantes muito bons e colocava algumas bolas no meio. Mesmo com a bola na mão eu procurava estes meus dois atacantes, até mesmo no fundo. Os meus dois atacantes eram ponteiros, o da frente não estava virando muito bola ai eu colocava no ponteiro que estava no fundo. A variação de jogo no mirim não é uma necessidade. Mirim Masculino ${ }^{1}$

Eu gosto de no início do set marcar bastante jogada e usar o meio, por exemplo, marcar uma de esmigo e soltar no atacante de meio. Assim deixo o central do outro time preso com o meu, seja passe 'A' ou 'B'. Já na metade do set avalio quem se encontra melhor e levantado para quem está pontuando, sempre procurando fazer $1 \mathrm{x} 1$. Infanto Masculino ${ }^{1}$ 
Cada adversário é uma forma de distribuição, pode-se iniciar jogando rápido pelo fundo $\mathrm{e}$ terminar com os jogadores mais abertos na rede ou a bola de primeiro tempo. Então, no começo do set você tem que conduzir o adversário a fazer o que você deseja, prender o bloqueio ou fazê-lo correr na rede. No final do set você surpreende o adversário com novas jogadas, dificultando ainda mais o sistema defensivo dele. Adulto Masculino

\section{Gestor de riscos}

A ação de arriscar durante uma partida é feita de forma controlada e, por outras vezes, é feita na tentativa de mudar todo o contexto de um jogo ou até mesmo, para criar situações novas com o intuito de surpreender o adversário (DÜRRWÄCHTER, 1984; QUEIROGA, 2005; QueIroga et al., 2010). Ficou demonstrada a gestão do risco do levantador tendo como primordial a manutenção da precisão ao ter que discernir se deve arriscar a execução do levantamento com o primeiro toque sendo de baixa qualidade, com o intuito de construir situações para o atacante contra bloqueio simples ou para criar situaçóes inesperadas pelo bloqueio adversário em momentos de pressão no placar.

... eu prefiro fazer uma coisa certinha do que querer inventar e não dar certo. Acho que no mirim você tem que arriscar menos, fazer um jogo mais seguro, geralmente as jogadoras não possuem as mesmas responsabilidades. Mirim Feminino ${ }^{2}$

... eu acho que no $24 \times 24$ tem que arriscar, mas arriscar com cabeça, tendo consciência da situação, colocar uma bola sabendo que vai chegar. Infanto Feminino ${ }^{1}$

... eu arrisco bola de meio mesmo com passe fora da mão, tem que saber até onde é possível forçar uma barra. Juvenil Feminino ${ }^{1}$

... é importante fazer coisas diferentes no jogo, criar, sem que se perca a precisão. Adulto Feminino

\section{Contra-comunicador}

O levantador de voleibol na contra-comunicação busca deixar os seus atacantes nas melhores condições possíveis. Para isto faz uso de fintas ou conduz o pensamento dos bloqueadores por meio da elaboração de situações com bloqueio simples ou sem bloqueio (MATIAS \& Greco, 2009; QueIroga, 2005; QueIroga et al., 2010). Ficou demonstrado a contra-comunicação do levantador na adaptação das suas tomadas de decisão em referência a estrutura do bloqueio adversário. ... se o bloqueio de meio se mover eu solto uma bola rápida no meu central ou na direção contrária ao movimento dele. Infanto Masculino ${ }^{1}$

... o levantador tem que saber para onde o bloqueio está indo, perceber algum movimento antecipado dele para colocar a bola em outro jogador. Infanto Feminino ${ }^{2}$

... percebo o bloqueio até o último momento, procuro algum sinal de movimentação nele, pé, perna, braço... se perceber uma movimento já faço uma bola rápida para o meio, ponta ou fundo, para que ele não possa chegar. Adulto Masculino

\section{Plasticidade técnica}

O levantador de voleibol deve possuir fácil manejo da bola e deve ser hábil (CLEMENs, 2005; Gilherme, 2001). Ficou demonstrada a qualidade técnica do levantador por meio da sua preocupação em executar com precisão o toque na bola, seja com o passe em condições ideais ou não. Além disto, o erro técnico no toque não perturba o levantador durante o jogo.

... procuro ir em todas as bolas sempre de toque, não tenho medo se uma bola vem rodando ou muito alta. Infanto Masculino ${ }^{1}$

... a gente tenta o máximo possível não utilizar a manchete, porque já temos o toque preciso, seja com passe chegando ou quebrado. Juvenil Masculino ${ }^{1}$

... erro é erro, não tem erro bonito ou feio. Erro pode ser você colocar uma bola chutada lá na arquibancada ou dar um dois toques, erro é erro. O levantador tem que buscar permanentemente a qualidade da precisão, ser preciso para todos os setores da quadra e em todas as velocidades. Adulto Masculino

\section{Visão de jogo}

A visão de jogo é um pré-requisito para a organização e orientação na ação tática a partir da percepção dos sinais relevantes (GRECO, 2002, 2009; 2002b; Matias \& Greco, 2009, 2010; Memmert, Simons \& Grimme, 2009; Serenini, Freire \& Noce, 1998; Williams, 2002a). Ficou demonstrada a visão de jogo do levantador por meio da percepção do sistema defensivo adversário, falhas e espaços 
no bloqueio e na defesa. Assim, sendo essencial perceber o bloqueio adversário no levantamento para o ataque e perceber a defesa no uso da bola da bola de segunda.

... o diferencial do levantador é a visão de jogo, ele pode até ter um bom toque e a bola sair paradinha, mas se joga apenas de forma robotizada, sem variação, sem visão de jogo, ele vai apenar ser um levantador de bola e nunca será um levantador de verdade. Infantil Masculino ${ }^{1}$

... o levantador tem que pensar o jogo inteiro, ver o posicionamento do bloqueio e da defesa, para uma bola de segunda, tem que ver o jogo para já no levantamento dificultar o funcionamento, a movimentação, do sistema defensivo do adversário. Juvenil Masculino ${ }^{2}$

... quando percebo que não tem ninguém na defesa adversária eu largo, não importa o momento do set. Vejo um espaço no bloqueio e na defesa eu vou lá e largo. Adulto Feminino

\section{Velocidade}

A velocidade é usada na distribuição de jogo do levantador com o objetivo de ludibriar o bloqueio adversário, por intermédio da maior velocidade dada à bola entre o levantamento e o ataque (MAtias \& Greco, 2009; Rocha \& Barbanti, 2004). Ficou demonstrada a velocidade na distribuição do levantador por meio do uso de bolas rápidas a partir das características técnicas dos próprios atacantes. Observa-se a preocupação em combinar a velocidade e a precisão no levantamento com o intuito de dificultar a ação dos três bloqueadores que se encontram na rede.

... nossas jogadoras são todas altas, às vezes faço uma jogada rápida, mas não sempre, porque na nossa categoria tem jogadoras altas, mas elas são lentas ainda, então é melhor jogar com bolas mais altas. Mirim Feminino ${ }^{2}$

... o levantador tem que se atrever a jogar mesmo, tem que dar velocidade ao jogo, até mesmo soltar bola de primeiro tempo com um passe difícil. Juvenil Masculino ${ }^{2}$

... durante o jogo a central vai fazendo melhor a leitura do meu jogo. Então procuro criar e usar mais a velocidade para dificultar a leitura de jogo dela. Adulto Feminino

\section{Dimensão: fontes de conhecimento}

\section{Treino}

A especialização na posição de levantador de voleibol requer treinos para aquisição-aprimoramento da precisão e da observação do bloqueio (GUILHERME, 2001; Matias, Silva \& Greco, 2005; Milistetd et al., 2009; ZanATTA, SouZa \& NASCimento, 2010). O desempenho do jogador em competição é uma consequência do que se fez no treino (ARAújo \& VolossoviTCH, 2005). Ficou demonstrado que o treino para o levantador de voleibol tem como objetivo a precisão das suas ações e a percepção do bloqueio adversário. Isto, por meio de treinamentos específicos com ou sem os demais atacantes. Também por meio do modo preparatório e corretivo, da relação entre receptor-levantador-atacante, no desdobramento do treino de situaçóes de jogo relativo ao sistema tático-estratégico da equipe aplicado nas competições. Tais treinamentos são efetuados com a intenção de se buscar um padrão em cada tipo de bola levantada para um atacante em particular.

... no começo o treino era só de precisão, para poder acertar as bolas com as atacantes na hora do jogo. Já no final do ano comecei a treinar observando o bloqueio adversário. Mirim Feminino ${ }^{2}$

... não adianta ter talento para ser um levantador de voleibol, não adianta ter força nas mãos e fazer a bola chegar na ponta, o levantador tem que treinar muito, tem que acertar a bola de cada um dos seus atacantes, tem que pegar consistência, padrão nas bolas e o treino específico ajuda muito. Tem que movimentar o jogo tendo padrão nas bolas. Infantil Masculino ${ }^{1}$

... acho que o levantador é a pessoa que mais tem que
treinar, a nossa função é muita repetição para que
se possa adquirir controle da bola. O treinamento
para o levantador é fundamental. Adulto Feminino

\section{Observação de jogo}

A observação de jogo permite que se tomem decisões durante uma partida tendo como base números sobre a eficácia das tomadas de decisões dos jogadores integrantes da própria equipe e da equipe adversária (COLEMAN, 2005; MATIAS \& GreCO, 2009). Ficou demonstrado que a observação de jogo é um ponto de partida para conhecimento do adversário, por meio do estudo em vídeo dos jogos destas equipes. Logo, o levantador determina a sua distribuição de jogo em referência a relação ataque-bloqueio: 
combinação das seis formações de ataque da própria equipe em relação às seis formações de bloqueio da equipe adversária.

... antes do jogo eu gosto de ver vídeo e ver principalmente se o meio fica o tempo todo marcando o meu central ou não. Infanto Masculino ${ }^{1}$

... a gente sempre procura ver vídeos antes para saber como que o outro time joga, mas eu sempre prefiro ir ver pessoalmente os outros times. Acaba um jogo e eu já me preocupo em ter informações a respeito do próximo time, para que possa saber os pontos fortes e fracos de cada um dos jogadores do time que irei enfrentar. Juvenil Masculino ${ }^{1}$

... a distribuição é feita a partir do momento que você vê o vídeo do outro time jogando, é feita baseada em números do outro time. Adulto Masculino

\section{Observação de levantadores mais experientes}

A observação de levantadores mais experientes permite a aquisição, análise e o conhecimento das açōes deste jogador em específico (QUEIROGA, 2005; Queiroga et al., 2010). Ficou demonstrado que a observação de levantadores experientes é um subsídio na formação e no desenvolvimento do levantador de voleibol, sobretudo a observação centrada em levantadores de referência no cenário internacional do voleibol.

... gosto muito de assistir os jogos da Seleção Brasileira Adulta e da Superliga, não fico prestando atenção onde está a bola, gosto de ver como o levantador se comporta na quadra, como ele se posiciona e a agilidade dele para chegar nas bolas. Mirim Feminino ${ }^{2}$

... eu procuro olhar os levantadores mais experientes, principalmente os da Superliga Masculina, por causa da velocidade de jogo deles. Infantil Feminino ${ }^{1}$

... achava fantástico o Mauricio Lima, observava ele para tirar coisas dele, ele me inspirou e inspira até hoje. Pude ver o trabalho dele bem de perto, ele é uma grande inspiração, uma referência que eu tenho como levantadora. Adulto Feminino

\section{Diálogo com o treinador}

O diálogo com o treinador é fundamental na preparação ou no auxilio das decisões do levantador de voleibol, antes ou durante uma partida, para aprimorar a interpretação do jogo (Botelho, Mesquita \&
Moreno, 2005a; Mesquita, 2005; QueIroga, 2005; QueIroga et al., 2010). O treinador, por intermédio da sua instrução verbal e não verbal, aconselha, motiva, opina, avalia, dirige, corrige, prescreve e informa os seus jogadores, para que estes consigam em todos os momentos adequar o seu comportamento tendo como meta o rendimento mais eficaz, em situações de treinamento e de competição (CRISPIN-SANTOS \& Rodrigues, 2004; GraÇA, 2005). Ficou demonstrado que o diálogo com o treinador fornece ao levantador de voleibol informações para construção de planos táticosestratégicos referentes à distribuição de jogo e correções destas decisões de distribuição no transcorrer do jogo. ... os técnicos me ajudam muito, eles são importantes para que eu melhore a minha visão de jogo com o treinamento. Infantil Masculino ${ }^{1}$

... acho que o técnico vê o jogo de fora, então é mais fácil para ele orientar alguma coisa. Mas às vezes tenho uma ideia diferente e a gente até debate algumas coisas. Juvenil Feminino ${ }^{2}$

... o técnico tem que ter conhecimento do jogo para poder conversar com o levantador e passar informações que irão ser importantes, mas o técnico tem ter sensibilidade para passar a informação o mais rápido possível, porque assim o levantador pode alterar o jogo. Adulto Masculino ${ }^{2}$

\section{Experiência refletida}

A experiência refletida permite aos jogadores uma performance sustentável, por meio da reflexão das suas ações e com a obtenção da autonomia para solucionar de forma positiva as situações de jogo (Rizola, Souza, Wueiroga, Scaglia \& Queiroga, 2004). Ficou demonstrado que o levantador está em constante aprendizado e sempre com o objetivo de se aperfeiçoar em sua posição de jogo.

... procuro sempre renovar, procuro ter curiosidade para renovar, sempre penso no que estou fazendo e procuro melhorar o meu jogo. Infanto Feminino ${ }^{2}$

... eu procuro sempre refletir sobre as coisas que faço e o que irei fazer dentro da quadra. Eu procuro treinar se cometo algum pecado ou se não estou conseguindo fazer alguma coisa, procuro treinar para corrigir. Juvenil Masculino ${ }^{1}$

... o levantador fica melhor com o passar dos anos, ele amadurece, tem uma segurança maior. O levantador tem que possuir paciência 
e tranquilidade, o jogo vai melhorar cada vez mais. Adulto Feminino

\section{Leitura}

A leitura como fonte de conhecimento teve baixa citação nos estudos de SAmulki, Albuquerque, Costa e Noce (2008), com atletas brasileiros de "taekwondo" e no de Rech, DARONGo, ETCHEPARE e ZINN (2003), com atletas de handebol do Brasil. O levantador de voleibol do escalão Infanto Masculino $^{2}$, do presente estudo, busca com o auxílio da leitura o conhecimento sobre liderança, para que possa exercê-la nos treinos e jogos.

... preocupo em ler sobre liderança, para poder ver como posso ajudar um jogador na hora do jogo, do treino ou até fora quadra. Procuro ler sempre para aprender como comandar o time na quadra. Infanto Masculino ${ }^{2}$

\section{Dimensão: indicadores de jogo para tomada de decisão tática Sub-dimensão: características das equipes}

\section{Características técnicas e táticas dos nossos atacantes}

Conhecer as características técnicas e táticas dos próprios atacantes permite ao levantador de voleibol elaborar suas decisões táticas, com a busca da extração do melhor rendimento de cada atacante (MATIAS \& Greco, 2009; QueIroga, 2005; QueIroga et al., 2010; Resende, 1995). De acordo com as características técnicas e táticas dos próprios atacantes, o levantador de voleibol tem a sua distribuição de jogo limitada. O desenvolvimento dos atacantes neste quesito permite ao levantador buscar novas opções em suas ações de jogo. ... gosto muito dele, ele é muito alto, tem 2,05 m com 14 anos de idade, é difícil pegar ele no bloqueio, porque ele é muito alto. Mas nem sempre eu jogo com ele, porque ele tem dificuldade de atacar longe da rede. Mirim Masculino ${ }^{2}$

... eu sempre chamava meus dois atacantes de meio no campeonato que vencemos, o passe vinha perto da linha dos três e então eu jogava com um chute para eles. Eles tinham muita habilidade, tinham o tempo certo para puxar e atacar a minha bola. Infanto Masculino ${ }^{2}$

... os meus ponteiros batem bola muito rápida, acelero o jogo com eles. Adulto Masculino

\section{Melhor atacante e o momento do jogo}

Os levantadores procuram e necessitam identificar um atacante de segurança, com o objetivo de usá-los nos momentos em que as suas opçôes de ataque são reduzidas ou nos momentos de pressão no placar: equipes em confronto tendo uma pontuação próxima uma da outra durante o set, na finalização do set e da própria partida (QueIroga, 2005; Queiroga et al., 2010). Ficou demonstrado que o melhor atacante e o momento do jogo são fatores determinantes para o levantador na opção da escolha ofensiva, sendo ativado o atacante com maior eficácia no momento final dos sets que se encontram em uma disputa ponto a ponto.

... atacante é uma questão de momento, no jogo o ser humano oscila muito, então em certo momento do jogo o atacante não vai virar muito e em outro momento vai virar todas as bolas. $\mathrm{O}$ levantador tem que possuir sensibilidade, perceber que tal cara está virando tudo, principalmente na hora que o jogo está difícil. Mirim Masculino ${ }^{1}$

... o placar de repente afeta, em um placar apertado, $24 \times 23,24 \times 24,25 \times 25$, você vai procurar seu jogador principal, pode até não ser o seu jogador principal no dia a dia, mas sim o jogador principal naquele jogo, naquele momento, é o que está resolvendo e colocando a bola no chão no dia. Infanto Feminino ${ }^{1}$

... o levantador tem que saber o placar e o momento de cada jogador durante o set, tem que saber como se encontra todo mundo durante ponto a ponto. Adulto Feminino

\section{Características psicológicas dos nossosatacantes}

O conhecimento do comportamento do atacante sobre suas expectativas, falhas e sucessos, associados aos diversos momentos do jogo é um indicativo que influencia as ações do levantador de voleibol (QueIroga, 2005; QueIroga et al., 2010), pois as emoções, como medo e raiva, afetam a qualidade do rendimento do atleta (Moraes \& Medeiros FilHo, 2009). Ficou demonstrado que o levantador de voleibol procurar sempre avaliar a confiança do atacante para determinar sua opção de levantamento.

... tem que levantar para todos os jogadores, porque se não vai desmotivar alguém, ou todo mundo, se eu concentrar o jogo apenas em um atacante. Então tem momentos que tem que ver como está psicologicamente cada atacante, 
pois se você levantar para alguém que esteja sem confiança já era. Infantil Masculino ${ }^{1}$

... sempre procuro ver como a pessoa se encontra em um momento de pressão, se ela não demonstrar coragem, disposição e confiança, eu não coloco bola nela. Juvenil Feminino ${ }^{2}$

... se depois de um bloqueio a pessoa abaixou a cabeça eu tento mudar a jogada, se ela olhou confiante para mim, eu geralmente repito a bola para ela continuar no jogo. Adulto Feminino

\section{Número de Atacantes}

Um maior número de atacantes envolvidos na ação ofensiva elaborada pelo levantador de voleibol gera maiores dificuldades nos bloqueadores adversários em perceber antecipadamente o atacante que receberá o levantamento (Matias \& GreCO, 2009; Palao, Santos \& Ureña, 2005). No escalão Mirim Masculino e Mirim Feminino os levantadores procuram concentrar o levantamento em um ou dois jogadores, com a progressão dos escalóes os levantadores aproveitam um maior número de atacantes. ... eu focava o jogo em dois atacantes muito bons e colocava algumas bolas no meio. Mirim Masculino ${ }^{1}$

... no mirim não é necessário ficar distribuindo o jogo, concentro o jogo em uma ou duas jogadoras, quando era preciso levantava algumas bolas do fundo para uma delas. Mirim Feminino ${ }^{2}$

... eu tento utilizar o máximo possível os atacantes, procuro dividir as bolas, para que o bloqueio adversário tenha que se preocupar com um número mais de atacantes. Juvenil Masculino²

... procuro jogar com todo mundo, solto bolas em todas as redes para os meus atacantes, de rede e de fundo, pois assim dificulto para o bloqueio. Juvenil Feminino ${ }^{2}$

... procuro fazer o jogo de modo que no final do set possa ter todos os atacantes preparados para receber a bola, poder colocar a bola em qualquer atacante dificulta demais a leitura do bloqueio. Adulto Feminino

\section{Características do saque adversário}

As características do saque adversário, como tipo [saque em apoio, saque flutuante e saque em suspensão (viagem ao fundo do mar)], local de execução do saque, trajetória, velocidade e direção imprimida à bola visam impedir a equipe adversária de efetuar recepções perfeitas, com o objetivo de diminuir o número de possibilidades ofensivas na distribuição do levantador (Gerbrands \& Murpy, 1995; Guilherme, 2001; WiSE, 2005). O saque em apoio e o saque flutuante visam condicionar as açôes do levantador ou diminuir a velocidade da sua distribuição, já o saque viagem visa o ponto direto ou uma maior quebra da velocidade da distribuição de jogo ou até mesmo a não organização ofensiva do adversário (Lirola, 2006; MONTEIRO, 1999; Urenā, Santos, Martínez, Calvo \& Oña, 2000; Urenã, Santos, Martínez, Calvo, Hernández \& Oña, 2001; Ureña, Calvo \& Pérez, 2002). Ficou demonstrado que conhecer as características do saque adversário pode mudar a distribuição de jogo, principalmente em saques forçados, como o saque em suspensão. Nestas situações os levantadores procuram simplificar a distribuição de jogo, uma vez que a recepção oferece um passe menos preciso.

... se tem um saque pesado vindo, tem que simplificar o jogo e colocar para rodar de primeira, depois eu levanto como faço mesmo. Infantil Feminino ${ }^{2}$

... se vejo que vai sacar uma jogadora que possui um saque viagem forte, eu já penso em algumas possibilidades diferentes e já sei que talvez tenha que correr e corrigir o passe. Juvenil Feminino ${ }^{2}$

... ao ver algumas jogadoras indo para o saque, eu até converso com as minhas atacantes, mas já temos tudo preparado, para saque forçado e saque tático. Às vezes um saque forçado pode nem quebrar o passe para o meu levantamento e o saque tático pode chegar na minha mão, mas pode prejudicar mesmo estando na minha mão, já que pode dificultar a trajetória de movimentação da atacante ou a velocidade dela. Adulto Feminino

\section{Características técnicas e táticas dos nossos passadores}

Os jogadores na recepção do saque devem ajustar-se aos diferentes tipos de saque, para cada situação existirá um posicionamento e uma execução ideal da manchete ou toque por cima. Sem uma boa recepção o levantador tem dificuldades em jogar com ataques rápidos e variados, desse modo facilita o sistema defensivo do adversário (GuILHERME, 2001; Matias \& GRECO, 2009; Rizola, 2003; ShONdel, 2005; UREÑA, Calvo \& PéreZ, 2002; Ureña et al., 2000, 2001). Ficou 
demonstrado que o levantador altera as suas ações de distribuição de jogo em decorrência das características técnicas e táticas dos jogadores da recepção.

... de acordo como vem o saque eu sei, mais ou menos, como vai ser o passe, pois sei as características de quem está passando. Mirim Masculino²

... tem meninas que possuem dificuldade para passar, deixo elas mais confortáveis para passar e ai me viro na mão. Juvenil Feminino ${ }^{2}$

... assim como a levantadora deve conhecer os seus atacantes ela deve saber também como as passadoras se comportam com os diferentes tipos de saque e momentos do jogo. Adulto Masculino

\section{Qualidade do primeiro toque}

Quando a qualidade do primeiro toque é baixa, as opçôes dos levantadores limitam-se basicamente a uma ação de correção, sendo difícil realizar um levantamento que coloque um dos atacantes com um bloqueador, ou com o bloqueio duplo não bem composto (QUEIROGA, 2005; Queiroga et al., 2010; Wise, 2005). Ficou demonstrado que a velocidade da distribuição de jogo é dependente da qualidade do primeiro toque, com uma baixa qualidade o levantador busca dar precisão ao seu levantamento sem se preocupar tanto em jogar contra o bloqueio adversário. O levantador busca variar o local em que vai receber o passe para ter uma forma diferente de organizar a movimentação dos atacantes e dificultar o bloqueio adversário.

... o passe não chegou à bola tem que ir para ponta ou saída com condições para o atacante virar. Por isto a precisão é muito importante no mirim. Se o passe vem na mão até que dá para fazer uma jogada, mas só assim mesmo. Mirim Masculino ${ }^{1}$

... o passe estourou não tem que inventar muito não, é colocar a bola redonda para o atacante ir lá e resolver. Tem momentos que gosto do passe no meio da quadra para poder fazer inversão e pra tempo e chute com o meio. Tem hora que gosto do passe mais entre a 2 e a 3 . Acho importante a variação do passe 'A' durante o jogo. Infanto Masculino

... hoje o saque é muito forte, então antes você poderia ter um passe um pouco mais para dois, um pouco mais para três, mas hoje o passe chegando em uma altura média no meio da quadra facilita a vida de todo mundo. Adulto Masculino

\section{Bloqueio adversário}

Os levantadores de voleibol procuram conhecer previamente e perceber durante o jogo a altura dos bloqueadores, o posicionamento tático, a técnica e a eficácia de cada um dos integrantes do bloqueio, para poder determinar a movimentação dos atacantes e entre estes qual será o ativado com base na falha do bloqueio (DÜrRWÄCHTER, 1984; SERENINI, FrEIRE $\&$ Noce, 1998; SuWAra, 2005). Ficou demonstrado que o levantador define suas ações de jogo tendo como referência as qualidades antropométricas, técnicas, táticas e de eficácia do bloqueio adversário. ... antes do jogo eu já procuro saber qual a altura do bloqueio adversário, quem bloqueia bem, quem joga o braço, porque tenho que procurar as jogadoras que possuem dificuldade de bloquear. Mirim Feminino ${ }^{2}$

... vejo se o bloqueio sai antes, se antecipa, se é lento, se é baixo, se é bom, olho antes e durante o jogo. Juvenil Feminino ${ }^{2}$

... eu sempre procuro saber a característica de todos os bloqueadores, a tática do sistema defensivo, como é a combinação do bloqueio, se marca 1 (corredor), se marca 2 (diagonal), se tem dificuldade em bola rápida ou se em bola alta, a entrada de braço, se tem eficiência em deslocar, a altura dos bloqueadores, isto é uma questão de análise de jogo, de números, então estamos sempre muito bem informados. Adulto Masculino

\section{Dimensão: indicadores de jogo para tomada de decisão tática Sub-dimensão: fluxo de jogo}

\section{Mudar para prevenir a adaptação do adversário}

A previsibilidade do voleibol decorrente da limitação em três toques na bola por equipe, nunca dois consecutivos pelo mesmo jogador, e a não existência de contato físico entre as equipes, faz com que seja exigido dos jogadores ações com cunho de imprevisibilidade. Logo, é necessário adaptar as ações de jogo no momento que o adversário começa a decifrar as decisões dos jogadores em quadra (MEsQUITA, 1996). Ficou demonstrado que o levantador de voleibol busca modificar preventivamente a distribuição do jogo com o intuito de evitar o fácil posicionamento final dos bloqueadores perante o atacante que recebe o levantamento. 
... às vezes tem bloqueio fechado, a gente procura usar mais as pontas, ai o bloqueio começa a abrir, ai começo a usar mais os meios, procuro sempre jogar de acordo com a marcação do bloqueio, procuro confundir ele. Infantil Feminino $^{2}$

... tem jogos que os bloqueadores nem percebem o que eu faço, só jogo com o meio e eles nem percebem. Quando o bloqueio percebe e começa a marcar o meu meio, fecham mais os bloqueadores, então eu começo a jogar mais com o meu ponteiro e com o oposto bem aberto. Infanto Masculino ${ }^{2}$

... o levantador tem que quebrar o ritmo de jogo, não pode ficar com as mesmas jogadas todo tempo, tem que variar para dificultar o trabalho do bloqueio. Adulto Feminino

\section{J ogar em relação ao bloqueio adversário}

A importância da intervenção do levantador está na construção ofensiva da equipe, para tal, utiliza o bloqueio adversário como indicador para suas ações (Queiroga, 2005; Queiroga et al., 2010). Ficou demonstrado que o levantador de voleibol busca na sua atuação, antes e durante o contado com a bola, perceber a intenção do bloqueio e suas características para dificultar a ação do sistema defensivo adversário.

... se o bloqueio estiver baixo o cara recebe bola, se o bloqueio for gigantesco não aciono, pode ficar de cara feia, mas se o time estiver rodando ele não vai receber bola. Infantil Masculino ${ }^{2}$

... o passe vem e eu estou olhando o bloqueio, principalmente o central, procuro sempre ler o bloqueio, mesmo eu vendo que o central do bloqueio acompanha sempre o meu central, eu procuro ver como estão os outros bloqueadores. Se acompanha o meu central eu jogo com chute na ponta ou tempo costa para o saída. Infanto Masculino $^{1}$

... percebo as bloqueadoras, o bloqueio se movimentar antes é melhor para que eu possa colocar uma bola contra simples ou até mesmo sem bloqueio. É melhor ainda se a jogadora de meio queima com a minha, ai posso até combinar uma bola no meio pra solta e ela vai bater sem bloqueio. Adulto Feminino

\section{Adaptaratécnicado passeeadireção domovimento}

O levantador de voleibol após perceber a qualidade do primeiro toque pode ter a necessidade de adaptar o próprio toque no instante do seu levantamento, com o intuito de facilitar a ação do atacante e dificultar a do bloqueio, para isto executa o toque tendo um contato mais breve ou prolongado com a bola e pode também diversificar a trajetória, a direção e a velocidade do levantamento (QUEIROGA, 2005; QueIroga et al., 2010). Observou-se que o levantador de voleibol busca adaptar a sua ação quando a recepção é de baixa qualidade, ou quando quer realizar uma jogada ofensiva diferenciada, ou quando percebe falha no bloqueio, ou percebe que o atacante não está preparado para receber o levantamento determinado, ou quer fintar o bloqueio, ou quer dar velocidade ou precisão ao levantamento.

... eu nunca encurto uma bola sem falar com a atacante, se encurto é porque o bloqueio não está chegando e a diagonal está livre, mas falo antes para a atacante. Infantil Feminino ${ }^{1}$

... pra passar de segunda só se o passe chegar desgrudado da rede e tem que ter um espaço do outro lado. Infanto Feminino ${ }^{2}$

... se o passe estiver quebrado eu prefiro fazer a bola chegar com qualidade para o atacante, não arrisco, é melhor ter neste caso a precisão no levantamento, colocar a bola no local exato para o atacante poder angular toda a quadra, mesmo que esteja um bloqueio duplo montado nele. Adulto Feminino

\section{Treinador}

O treinador procura interromper o jogo, mudar o fluxo de jogo, através do pedido de tempo para se comunicar com seus jogadores, quando sua equipe não está com posse do saque e/ou perde mais de três pontos consecutivos durante o set. A partir do vigésimo ponto a solicitação de tempo possui uma maior frequência com o objetivo de se obter a vitória no set (ARROYO, ÁlLVREZ \& CAMPO, 2003; Botelho, Mesquita \& Moreno, 2005a). Os atletas em situação de treino e competição trazem consigo conhecimento, capacidades motivações e expectativas, não são elementos passivos em seus contextos esportivos (GRAÇA, 2005). O treinador fica tentado a emitir informação durante o decorrer do jogo, já que é autorizado o seu posicionamento ao lado da zona de jogo. Assim, fornece informações mesmo 
em situaçôes sem necessidade. Logo, o treinador pode emitir informaçôes com excesso, desviando a atenção dos jogadores e dificultando o "feedback" intrínseco (Botelho, Mesquita \& Moreno, 2005b). Ficou demonstrado que o levantador de voleibol prefere atuar com independência na sua distribuição de jogo, sendo as orientaçôes do treinador, no transcorrer da partida, assimiladas em situaçôes de baixo rendimento ofensivo da equipe. ... o técnico tem que dar independência para o levantador atuar, só em certos momentos pedir para o levantador colocar tal bola para poder fechar o jogo. Sentiu também que o levantador está forçando muito o jogo, o técnico deve falar com o levantador. Mas acho que o técnico não pode ficar comandando o levantador jogada a jogada, apenas em alguns momentos do jogo. Infantil Masculino ${ }^{1}$

... o técnico tem que deixar o levantador com liberdade, eu não consigo jogar se ele ficar o tempo todo dando ordens no meu ouvido. Caso eu tenha errado uma ou outra bola é bom ouvir o técnico, o meu técnico me dá liberdade, só me dá algumas dicas. Na hora do tempo ele não fala nada comigo, porque vê que o jogo está fluindo. Mas quando começo a jogar com bola alta na ponta ele pede para que eu acelere o jogo, mas já me acostumei com as falas dele, pois já escutei muito na minha cabeça. Então ele nem precisa falar comigo, fala mais com os atacantes. Juvenil Masculino ${ }^{1}$

... o técnico na quadra deve auxiliar o levantador dentro da tática que o levantador está desenvolvendo durante o jogo. O levantador tem que ter uma linha de pensamento e o técnico dentro dela deve auxiliar o levantador. Se não fica muito difícil, pois quem joga é o levantador. Adulto Feminino

\section{Situações imprevistas}

As situações imprevistas podem ocorrer quando há déficits nas ações de jogo realizadas ou mesmo quando ocorrem ações inesperadas no transcorrer $\mathrm{da}$ partida (QueIroga, 2005; QueIroga et al., 2010). Ficou demonstrado que o levantador evita ao máximo o uso da manchete em seus levantamentos, mas há situaçôes que o uso desse recurso é inevitável, consequência da baixa qualidade do primeiro toque. ... eu uso a manchete só em último caso, quando não tem jeito, só em último caso, só com a bola baixa demais. Se a bola vier alta demais eu não vou de manchete, firmo o dedo e dou uma dedada nela, mesmo que dê barulho. Infantil Masculino ${ }^{1}$

... tem bola estourada que não tem como chegar de toque, bola baixa, tem quer colocar para cima para o atacante de manchete mesmo, mas tem que colocar com a mesma precisão do toque. Mas o melhor é não usar a manchete, é bom ouvir que o levantador chega de toque em todas as bolas. Mas os passes que vem abaixo do joelho e os que estouram a $4 \mathrm{~m}$ atrás da linha de fundo não tem como ir de toque, tem que levantar de manchete. Infanto Feminino ${ }^{2}$

... o levantador tem que chegar rápido na bola, não pode deixar ela abaixar demais, tem sempre que tocar, manchete tem que ser usada pouquíssimas vezes, quebra todo o ritmo de jogo. Adulto Feminino

\section{Conclusões}

Por meio da abordagem qualitativa aplicada neste estudo e pelos resultados apurados, verifica-se que os levantadores em momentos decisivos dos jogos e dos campeonatos buscam concentrar o produto final da distribuição em poucos atacantes. Os levantadores optam em não usar todas as possibilidades ofensivas, mesmo que isto ocasione situaçōes desfavoráveis ao atacante em relação ao bloqueio adversário e até mesmo com o passe (recepção ou defesa) em boas condiçôes a distribuição fica limitada. Isto ocorre em detrimento da condição inferior no processo decisório de um atacante em relação a outro, seja tático-estratégico (cognitivo) e/ou técnico (motor), bem como por dificuldades psicológicas do próprio atacante dentro do contexto do jogo, como falta de confiança.

Além disto, os resultados sugerem que os escalōes de competição anteriores ao escalão adulto no Voleibol Brasileiro (Mirim, Infantil, Infanto e Juvenil), têm na forma de jogo deste escalão um modelo indicativo de jogo. Isto, pois, há uma compreensão tático-estratégica semelhante entre os levantadores de diversos escalóes. Contudo, os levantadores de escalōes iniciais de competição declaram uma 
limitação processual dos integrantes da equipe e dele próprio, em todas as esferas que englobam diretamente a distribuição de jogo: recepção, levantamento e ataque.

O processo de ensino-aprendizagem-treinamento tático-técnico deve possibilitar o desenvolvimento mais amplo e não se concentrar nas qualidades cognitivas, motoras, antropométricas, fisiológicas e psicológicas de um reduzido número de integrantes da equipe. Deste modo, o levantador terá maior possibilidade de construir situações ofensivas, sobretudo em momentos decisivos, que acarretarão na conquista do ponto, do jogo e do campeonato. $\mathrm{O}$ resultado do presente estudo, as explanaçōes dos levantadores nas categorias de cada uma das dimensões, poderá contribuir com os treinadores na formatação dos treinos e na organização táticoestratégica dos levantadores no decorrer dos jogos.
Neste estudo houve semelhança entre as categorias do conhecimento tático-estratégico do levantador que emergiram em relação às pesquisas científicas anteriores referentes à grelha do Conhecimento tático-estratégico do levantador de voleibol. Novas categorias também emergiram em duas dimensões desta grelha: Leitura (Fonte de Conhecimento), Número de atacantes, Características do saque adversário, Características técnicas e táticas dos nossos passadores (Indicadores de jogo para tomada de decisão tática, sub-dimensão Características das equipes) e Treinador (Indicadores de jogo para tomada de decisão tática, sub-dimensão Fluxo de jogo). Estas novas categorias poderão ser inseridas nesta grelha ou em um contínuo destes estudos, para futuras investigações científicas com abordagem qualitativa, em busca de uma maior compreensão sobre o levantador da Escola Brasileira de Voleibol.

\begin{abstract}
Knowledge tactical-strategic of setter's champions Brazilian volleyball: members of teams adolescent and adult high level

The aim of this study was to identify strategic-tactical knowledge of the setter's of different categories. We analyzed the organization of offensive action of 18 setter's of both sexes, champions at São Paulo and Minas Gerais, under-14 old age, under-15 old age, under-17 old age, under-20 old age and Adult champion (Professional) Men's and Women's at Brazilian National Championship (Superliga). It was used a semi-structured and individual interview with reference in aspects of knowledge tactical and strategic of setter (Mesquita \& GRAÇA, 2002a, 2002b; Queiroga, 2005; Queiroga et al., 2010). The texts of 18 semi-structured interviews were coded, compared and grouped by similarity of meaning (DUARTE, 2002; Jones, 2005; Minayo \& Sanches, 1993; Thomas \& Nelson, 2002). The results showed that the setter, even with ideal conditions of quality of pass, focuses its actions to certain striker's, for not having trust in others players and because attacking tactics and technical limitations of the other players in their final offensive actions. Furthermore, was noted that the setters are in constantly development, independent of how many years they are playing volleyball, they are said how important a training as a knowledge source, and others more is.
\end{abstract}

UnIteRMs: Cognition and action; Setter; Distribution; Volleyball.

\title{
Referências
}

ALLARD, F. Cognition, expertise and motor performance. In: STARKES, J.L.; ALLARD, F. (Eds.). Cognitive issues in motor expertise. Amsterdam: Elsevier Science, 1993. p.17-34.

ALLARD, F.; BURNETT, N. Skill in sport. Canadian Journal of Psychology, Quebec, v.39, n.2, p.294-312, 1985. ALVES, J. Maestria e rendimento desportivo: o papel da percepção. Revista Portuguesa de Ciências do Desporto, Porto, v.4, n.2, p.38-42, 2004.

ANDERSON, J.R. The architecture of cognition. Harvard: Harvard Univesity Press, 1983. 
. Cognitive psychology and their acquisition. Psychological Review, Washington, v. 94, n.1, p.192-210, 1995. ARAÚJO, D.; VOLOSSOVITCH, A. Fundamentos para o treino da tomada de decisão: uma aplicação ao handebol. In: ARAÚJO, D. (Ed.). O contexto da decisão, a acção táctica no desporto. Lisboa: Visão e Contextos, 2005, p.75-98. ARROYO, P.M.; ÁLVAREZ, F.V.; CAMPO, J.A.S. Estudio de la conducta verbal del entrenador de voleibol durante la competición. In: MESQUITA, I.; MOUTINHO, C.A.S.S.; FARIA, R. (Eds.). Investigação em voleibol: estudos ibéricos. Porto: FCDEF-UP, 2003. p.49-58.

BANKS, A.P.; MILLWARD, J. Differentiating knowledge in teams: effect of shared declarative and procedural knowledge on team performance. Group Dynamics, Theory, Research, and Practice, Washington, v.11, n.2, p.95-106, 2007. BIZZOCCHI, C. O voleibol de alto nível. São Paulo: Fazenda Arte Editorial, 2000.

BOTELHO, S.; MESQUITA, I.; MORENO, M.P. Análises das intervenções verbais dos treinadores de voleibol na competição, nos períodos antes do jogo e nos intervalos entre os sets. Estudo comparativo em função do sexo das equipes. In: PINTO, J. (Ed.) Estudos. Porto: Faculdade de Desporto da Universidade do Porto, 2005a. p.167-74.

. A intervenção verbal do treinador de voleibol na competição: estudo comparativo entre equipes masculinas e femininas dos escalōes de formação. Revista Portuguesa de Ciências do Desporto, Porto, v.5, n.2, p.174-83, 2005 b. CAMPOS, C.J.G. Método de análise de conteúdo: ferramenta para a análise de dados qualitativos no campo da saúde. Revista Brasileira de Enfermagem, Brasília, v.57, n.5, p.611-4, 2004.

CAREGNATO, R.C.A.; MUTTI, R. Pesquisa qualitativa: análise de discurso versus análise de conteúdo. Revista Texto \& Contexto Enfermagem, Florianópolis, v.15, n.4, p.679-84, 2006.

CLEMENS, T. Levantamento. In: SHONDELL, D.; REYNAUD, C. (Eds.). A bíblia do treinador de voleibol. São Paulo: ArtMed, 2005. p.193-202.

COLEMAN, J. Analisando os adversários e avaliando o desempenho da equipe. In: SHONDELL, D.; REYNAULD, C. (Eds.). A bíblia do treinador de voleibol. Porto Alegre: ArtMed, 2005. p.315-38.

CORRÊA, D.K.A. A construção de competências coletivas em equipes esportivas: o caso do futebol. 2004.140 f. Dissertação (Mestrado em Administração) - Escola de Administração, Universidade Federal do Rio Grande do Sul, Porto Alegre, 2004. CORTES, V.M.S. Técnica de coleta e análise qualitativa de dados. Cadernos de Sociologia, Porto Alegre, v.9, n. 1, p.11-47, 1998. COSTA J.C.; GARGANTA, J.A.; FONSECA, A.; BOTELHO, M. Inteligência e conhecimento específico em jovens futebolistas de diferentes níveis competitivos. Revista Portuguesa de Ciências do Desporto, Porto, v.2, n.4, p.7-20, 2002. CRISPIN-SANTOS, A.; RODRIGUES, J. Análise da instrução de treinador de futebol: comparação entre a prelecção e a competição. Revista Portuguesa de Ciências do Desporto, Porto, v.4, n.2, p.190, 2004. Suplemento.

DORON, R.; PAROT, F. Dicionário de psicologia. São Paulo: Ática, 2002.

DUARTE, R. Pesquisa qualitativa: reflexões sobre o trabalho de campo. Caderno de Pesquisa, São Paulo, n.115, p.139-54, 2002. DÜRRWÄCHTER, G. Voleibol: treinar jogando. Rio de Janeiro: Livro Técnico, 1984.

FRENCH, K.; McPHERSON, S.L. Adaptations in response selection processes used during sport competition with increasing age expertise. International Journal of Sport Psychology, Rome, v.30, n.2, p.173-93, 1999.

FRENCH, K.; NEVETT, M.E.; SPURGEON, J.H.; GRAHAM, K.C.; RINK, J.E., McPHERSON, S.L. Knowledge representation and problem solution in expert and novice youth baseball players. Research Quarterly for Exercise and Sport, Washington, v.67, n.4, p.386-95, 1996.

GARGANTA, J. Conhecimento e acção nos jogos desportivos. Revista Portuguesa de Ciências do Desporto, Porto, v.4, n.2 p.55-6, 2004. Suplemento.

O treino da táctica e da estratégia nos jogos desportivos. In: GARGANTA, I. (Ed.). Horizontes e órbitas no treino dos jogos desportivos. Porto: CEJD/FCDEF/Universidade do Porto, 2000. p.51-61.

- (Re)Fundar os conceitos de estratégia e táctica nos jogos desportivos colectivos, para promover uma eficácia superior. Revista Brasileira de Educação Física e Esporte, São Paulo, v.20, p.201-3, 2006. Suplemento n.5.

GARGANTA, J.; GRÉHAIGNE, J.F. Abordagem sistêmica do jogo de futebol: moda ou necessidade? Movimento, Porto Alegre, v.5, n.10, p.40-50, 1999.

GARGANTA, J.; OLIVEIRA, J. Estratégia e táctica nos jogos desportivos coletivos. In: OLIVEIRA, J.; TAVARES, F. (Eds.). Estratégia e táctica nos jogos desportivos coletivos. Porto: CED. 1996. p.7-24.

GIACOMINI, S.D. Conhecimento tático declarativo e processual no futebol: estudo comparativo entre estudo de diferentes categorias e posições. 2007. 161f. (Mestrado em Educação Física: Treinamento Esportivo) - Escola de Educação Física, Fisioterapia e Terapia Ocupacional, Universidade Federal de Minas Gerais, Belo Horizonte, 2007.

GERBRANDS, T.; MURPY, P. Conseqüências da mudança da zona de saque. RevistaVôlei Técnico, Rio de Janeiro, v.2, n.5, p.5-11, 1995. GIACOMINI, S.D.; GRECO, P.J. Comparação do conhecimento tático processual em jogadores de futebol de diferentes 
categorias e posições. Revista Portuguesa de Ciências do Desporto, Porto, v.8, n.1, p.126-36, 2008.

GRAÇA, A. Melhorar a capacidade instrucional de treinadores de jovens. Revista Perfil, Porto Alegre, v.2, n.8, p.13-5, 2005. GRECO, P.J. Cogni(a)cão: conhecimento, processos cognitivos e modelos de ensino-aprendizagem-treinamento para o desenvolvimento da criatividade (tática). Revista Portuguesa de Ciências do Desporto, Porto, v.4, n.2, p.56-9, 2004. Suplemento. - Conhecimento tático-técnico: modelo pendular do comportamento e da ação nos esportes coletivos. Revista

Brasileira de Psicologia do Esporte e do Exercício, Belo Horizonte, v.0, n.1, p.107-29, 2006a.

- Conhecimento tático-técnico: eixo pendular da ação tática (criativa) nos jogos esportivos coletivos. Revista

Brasileira de Educação Física e Esporte, São Paulo, v.20, p.210-2, 2006b. Suplemento n.5

. O ensino-aprendizagem-treinamento dos esportes coletivos: uma análise inter e transdiciplinar. In: SILAMI, G.E.;

LEMOS, M.L.K. (Eds.). Temas atuais VII educação física e esportes. Belo Horizonte: Health, 2002, p.53-8.

- O ensino do comportamento tático nos jogos esportivos coletivos: aplicação no handebol. 1995. $224 \mathrm{f}$.

(Doutorado em Psicologia Educacional) - Faculdade de Educação, Universidade Estadual de Campinas, Campinas, 1995. . Percepção. In: SAMULSKI, M.D. (Ed.). Psicologia do esporte: conceitos e novas perspectivas. Barueri: Manole, 2009. p. 57-84.

GRECO, P.J.; BENDA, N.R. Iniciação esportiva universal: da aprendizagem motora ao treinamento técnico. Belo Horizonte: Editora UFMG, 1998. v.1.

GUILHERME, A. À beira da quadra. Belo Horizonte: Minas Tênis Clube, 2001.

HAGEDORN, G. Taktik und strategie. In: RÖTHIG, P.; PROHL, R. (Eds.). Sportwissenschaftliches Lexikon. Schorndorf: Hofmann, 2003.

HENKE, K. A model for memory systems based on processing modes rather than consciousness. Nature Reviews Neuroscience, Cincinati, v.11, n.7, p.523-32, 2010.

JONES, P.F. Pesquisa qualitativa. In: THOMAS, J.R.; NELSON, J.K.; SILVERMAN, J.S. (Eds.). Métodos de pesquisa em atividade física. Porto Alegre: ArtMed, 2005. p.279-96.

KELLMANN, M.; BECKMANN, J. Research and intervention in sport psychology: new perspectives on an inherent conflict. International Journal of Sport and Exercise Psychology, Kansas, v.1, n.1, p.13-26, 2003

KRÖGER, C.; ROTH, K. Escola da bola: um ABC para iniciantes nos jogos esportivos. São Paulo: Phorte, 2002.

LAGUNA, M. Adaptar o treino à natureza do desporto que se prática. In: ARAÚJO, D. (Ed.). O contexto da decisão, a acção táctica no desporto. Lisboa: Visão e Contextos, 2005. p.100-6.

LIROLA, D.C. Research and analysis of the serve in the current high performance men's volleyball. International Journal of Sport Science, n.5, p.12-28, 2006.

LUNA, B.F. Sequência básica na elaboração de protocolos de pesquisa. Arquivo Brasileiro de Cardiologia, Rio de Janeiro, v.71, n.6, p.735-40, 1998

MARCELINO, R.; MESQUITA, I.; SAMPAIO, J.; MORAES, J.C. Estudo dos indicadores de rendimento em voleibol em função do resultado do set. Revista Brasileira de Educação Física e Esporte, São Paulo, v.24, n.1, p.69-78, 2010. MARONI, F.C.; MENDES, D.R.; BASTOS, F.C. Gestão do voleibol no Brasil: o caso das equipes participantes da Superliga 2007-2008. Revista Brasileira de Educação Física e Esporte, São Paulo, v.24, n.2, p.239-48, 2010.

MATIAS, C.J.A.S.; GRECO, P.J. Análise de jogo nos esportes coletivos: a exemplo do voleibol. Pensar a Prática, Goiânia, v.12, n.3, p.1-15, 2009.

. Cognição e ação nos jogos esportivos coletivos. Ciências \& Cognição, Rio de Janeiro, v.15, n.1, p.252-71, 2010. MATIAS, C.J.A.S.; SILVA, S.A; GRECO, P.J. As qualidades atribuídas pelos técnicos das seleçôes brasileiras de voleibol na definição do levantador ideal. The FIEP Bulletin, Montes Claros, v.76, p.127, 2005. Special edition.

MANN, D.Y.; WILLIAMS, A.; WARD, P.; JANELLE, C.M. Perceptual-cognitive expertise in sport: a meta-analysis. Journal of Sport and Exercise Psychology, Champaing, v.29, n.4, p.457-78, 2007.

McPHERSON, S.L. The developmental of expertise: mapping the tactical domain. Quest, Champaign, v.46, n.2, p. 223-40, 1994. McPHERSON, S.; KERNODLE, M. Mapping two new points on the tennis expertise continuum: tactical skills of adult advanced beginners and entry professionals during competition. Journal of Sport Sciences, London, v.25, n. 8, p.945-59, 2007. McMORRIS, T. Cognitive developments and the acquisition of decision-making skills. International Journal of Sport Psychology, Rome, v.30, n.2, p.151-72, 1999.

MEMMERT, D.; SIMONS, D.J.; GRIMME, T. The relationship between visual attention and expertise in sports. Psychology of Sport \& Exercise, Amsterdam, v.10, n.1, p.146-51, 2009.

MESQUITA, I. A contextualização do treino no voleibol: a contribuição do construtivismo. In: ARAÚJO, D. (Ed.). O contexto da decisão - acção táctica no desporto. Lisboa: Colecção Visão e Contextos das Ciências do Desporto. 2005. p.355-78. 
. Contributo para a estruturação das tarefas no treino em voleibol. In: OLIVEIRA, J.; TAVARES, F. (Eds.). Estratégia e táctica nos jogos desportivos coletivos. Porto: CED. 1996. p.95-103.

MESQUITA, I.; GRAÇA, A. Conhecimento estratégico de um levantador de alto nível. Revista Treino Esportivo, Lisboa, v.17, p.15-20, 2002a.

. Probing the strategic knowledge of an elite volleyball setter: a case study. International Journal of Volleyball Research, Austin, v.5, n.1, p.6-12, 2002 b.

MILISTETD, M.; MESQUITA, I.; NASCIMENTO, J.V.; SOUSA SOBRINHO, A.E.P. Concepções dos treinadores "experts" brasileiros sobre o processo de formação desportiva do jogador de voleibol. Revista Brasileira de Educaçáo Física e Esporte, São Paulo, v.24, n.1, p.79-93, 2010.

A concepção de treinadores "experts" brasileiros acerca do processo de especialização funcional na formação desportiva a longo prazo do jogador de voleibol. Revista da Educação Física, Maringá, v.20, n.2, p.161-70, 2009.

MINAYO, M.C.S.; MINAYO, M. O desafio do conhecimento. São Paulo: Hucitec, 1999.

MINAYO, M.C.S.; SANCHES, O. Quantitativo-qualitativo: oposição ou complementaridade? Caderno de Saúde Pública, Rio de Janeiro, v.9, n.3, 1993, p.239-62, 1993.

MONTEIRO, A.V. Eficiência do serviço em voleibol. In: TAVARES, F. (Ed.). Estudos 2. Porto: FCDEF-UP, 1999. p.131-58. MORAES, L.C.C.A.; MEDEIROS FILHO, E.S. Expertise no esporte: desenvolvimento da excelência. In: SAMULSKI, D.M. Psicologia do esporte: conceitos e novas perspectivas. Barueri: Manole, 2009. p.429-46.

MOREIRA, M.; FREITAS, D.M. A criatividade como alavanca para uma melhor gestão desportiva. Revista Portuguesa de Ciências do Desporto, Porto, v.9, n.2, p.17-25, 2009.

NOCE, F. Liderança. In: SAMULSKI, D. (Ed.). Psicologia do esporte. Manole: Barueri, 2002. p.219-48.

PALAO, J.M.; SANTOS, J.A.; UREÑA, A. Effect of the setter's position on the block in volleyball. International Journal of Volleyball Research, Austin, v.6, n.1, p.29-32, 2004.

. The effect of the setter's position on the spike in volleyball. Journal of Human MovementStudies, New York, v.48, n.1, p.25-40, 2005. PLATONOV, V.N. A preparação tática do desportista. In: PLATONOV, V.N. (Ed.). Tratato geral de treinamento desportivo. São Paulo: Phorte, 2008. p.370-380.

PASQUALI, L. Psicometria: teoria dos testes na psicologia e na educação. Petrópolis: Vozes, 2004.

Validação dos testes psicológicos: será possível reencontrar o caminho? Psicologia: Teoria e Prática, Brasília, v.23, p.99-107, 2007. Número especial.

QUEIROGA, F. As atitudes dos atletas relativamente ao psicólogo do desporto: da tradução e adaptação de um instrumento à sua aplicação com atletas brasileiros de diferentes modalidades esportivas. 2004. $111 \mathrm{f}$. (Mestrado em Desporto para Crianças e Jovens) - Faculdade de Ciências do Desporto e de Educação Física, Universidade do Porto, Porto, 2004. QUEIROGA, M.A. O conhecimento táctico-estratégico do distribuidor de alto nível: um estudo com os distribuidores das seleções brasileiras de voleibol feminino e masculino. 2005. 180 f. (Mestrado em Treino de Alto Rendimento) - Faculdade de Ciências do Desporto e de Educação Física, Universidade do Porto, Porto, 2005.

QUEIROGA, M.A.; MATIAS, C.J.A.S.; GRECO, P.J.; GRAÇA, A.; MESQUITA, I. A dimensão do conhecimento táticoestratégico do levantador de alto nível: um estudo realizado com levantadores da seleção brasileira de voleibol. Revista Mineira de Educação Física, Viçosa, n.2, p.111-9, 2005. Volume especial.

QUEIROGA, M.A.; MATIAS, C.J.A.S.; MESQUITA, I.; GRECO, P.J. O conhecimento tático-estratégico dos levantadores integrantes das seleçōes brasileiras de voleibol. Fitness \& Performance Journal, Rio de Janeiro, v.9, n.1, p.78-92, 2010. QUINTANA, M.S; ROMAN, I.R.; CALVO, A.L.; MOLINUEVO, J.S. Perceptual visual skills in young highly basketball players. Perceptual and Motor Skill, Missoula, v.104, n.2, p.547-61, 2007.

RAMOS, P.K.H.M.; NASCIMENTO, V.J.; DONEGA, L.A.; NOVAES, J.A.; SOUZA, R.R.; SILVA, J.T.; LOPES, S.A. Estrutura interna das ações de levantamento das equipes finalistas da superliga masculina de voleibol. Revista Brasileira de Ciência e Movimento, Brasília, v.12, n.4, p.33-7, 2004.

RECH, C.R.; DARONCO, A.; ETCHEPARE, L.S.; ZINN, L.J. Avaliação psicossocial de atletas de handebol feminino juvenil da cidade de Santa Maria - RS. Lecturas: Educación Física y Deportes, Buenos Aires, v.9, n.60, p.1-3, 2003.

RESENDE, B. Levantador, uma simples questão de personalidade. Revista Vôlei Técnico, Rio de Janeiro, v.1, n.3, p.5-11, 1995. RIZOLA, A.N. Uma proposta de preparação para equipes jovens de voleibol feminino. 2003. 135 f. (Mestrado em Educação Física: Ciência do Desporto) - Faculdade de Educação Física, Universidade Estadual de Campinas, Campinas, 2003. RIZOLA, A.N.; SOUZA, A.; QUEIROGA, M. SCAGLIA, A.; QUEIROGA, F. Utilização da abordagem ecológica no voleibol para criação de sessões de treinamento em busca da performance sustentável. Revista Portuguesa de Ciências do Desporto, Porto, v.4, n.2, p.371-2, 2004. Suplemento. 
RINK, J.; FRENCH, K.; TJEERDSMA, L. Foundations for the learning and instruction of sport games. Journal of Teaching and Physical Education, Champaign, v.15, n.4, p.339-417, 1996.

ROCHA, D.; DEUSDARÁ, B. Análise de conteúdo e análise de discurso: aproximações e afastamentos na (re)construção de uma trajetória. ALEA: Estudos Neolatinos, Rio de Janeiro, v.7, n.2, p.305-22, 2005.

ROCHA, M.C.; BARBANTI, V.J. Uma análise dos fatores que influenciam o ataque no voleibol masculino de alto nível. Revista Brasileira de Educação Física e Esporte, São Paulo, v.18, n.4, p.303-314, 2004.

SAMULSKI, D.M. Emoções no esporte. In: SAMULSKI, D.M. (Ed.) Psicologia do esporte: manual para a educação física, psicologia e fisioterapia. São Paulo: Manole, 2002. p.133-51.

SAMULSKI, D.M.; ALBUQUERQUE, M.R.; COSTA, V.T.; NOCE, F.; Avaliação do perfil motivacional dos atletas de alto rendimento do taekwondo brasileiro. Revista Iberoamericana de Psicologia Del Ejercicio y El Deporte, Sevilla, v.3, n.1, p.75-94, 2008.

SAMULSKI, D.M.; NOCE, F.; CHAGAS, M.H. Estresse. In: SAMULSKI, D.M. Psicologia do esporte: manual para a educação física, psicologia e fisioterapia. São Paulo: Manole, 2002. p.157-95.

SERENINI, P.L.A.; FREIRE, B.A.; NOCE, F. Voleibol. In: GRECO, P.J. Iniciação esportiva universal: metodologia da iniciação esportiva na escola e no clube. Belo Horizonte: Editora UFMG. 1998. v.2.

SHONDELL, S. Recebendo saques. In: SHONDELL, D.; REYNAUD, C. (Eds.). A bíblia do treinador de voleibol. São Paulo: ArtMed, 2005. p.193-202.

STERNBERG, R.J. Processos de memória. In: STERNBERG, R.J. Psicologia cognitiva. 4. ed. Porto Alegre: ArtMed, 2008. p.190-220.

SUAIDEN, S.; BARROS, F.J.; AZEVÊDO, P.H. Caracterização do perfil do gestor esportivo dos clubes da primeira divisão de futebol do distrito federal e suas relaçôes com a legislação esportiva brasileira. Revista de Educação Física, Maringá, v.15, n.1, p.33-42, 2004.

SUWARA, R. Bloqueio. In: SHONDELL, D.; REYNAUD, C. (Eds.). A bíblia do treinador de voleibol. São Paulo: ArtMed, 2005. p.241-57.

TENENBAUM, G. Expert athletes: an integrated approach to decision making. In: STARKES, J.; ERICSSON, A. (Eds.). Expert performance in sports: advances in research on sport expertise. Champaing: Human Kinetics, 2003. p.191-218. THOMAS, J.; FRENCH, K.; HUMPHRIES, C.A. Knowledge development and sport skill performance: diretions of motor behaviour research. Journal of Sport Psychology, London, n.8, p.259-72, 1986.

THOMAS, J.R.; NELSON, J.K. Métodos de pesquisa em atividade física. 5.ed. Porto Alegre: ArtMed, 2002.

THOMAS, J.R.; NELSON, J.K.; SILVERMAN, J.S. Pesquisa experimental e quase-experimental. In: THOMAS, J.R.; NELSON, J.K.; SILVERMAN, J.S. (Eds.). Métodos de pesquisa em atividade física. Porto Alegre: ArtMed, 2005.

TURNER, A.; MARTINEK, T. Teaching for understanding: a model for improving decision making during game play. Quest, Champaign, v.44, n.1, p.44-63, 1995.

UREÑA, A.; CALVO, R.; PÉREZ, L. A study of serve reception in the top-level of spanish male volleyball after the introduction of the libero player. Revista Internacional de Medicina y Ciencias de la Atividade Física y el Deporte, Madrid, v.2, n.4, p.37-49, 2002.

UREÑA, A.; SANTOS, J.A.; MARTÍNEZ, M.; CALVO, R.; HERNÁNDEZ, E.; OÑA, A. El principio de variabilidad como factor determinante en lá táctica individual del saque en voleibol masculino de nivel internacional. Revista Motricidad, Madrid, v.7, p.63-74, 2001.

UREÑA, A.; SANTOS, J.A.; MARTÍNEZ, M.; CALVO, R.; OÑA, A. La facilitación defensiva a através del saque en el voleibol femenino de alto nível. Revista Motricidad, Madrid, v.6, p.175-89, 2000.

VILHENA, M.S.; GRECO, P.J. A influência dos métodos de ensino-aprendizagem-treinamento no desenvolvimento da inteligência e da criatividade tática em atletas de futsal. Revista Brasileira de Educação Física e Esporte, São Paulo, v.23, n.3, p.297-307, 2009.

WILLIAMS, M. Perceptual and cognitive expertise in sport. The Psychologist, London, v.15, n.8, p.416-7, 2002a. . Visual search behavior in sport. Journal of Sports Sciences, London, v.20, n.3, p.169-70, 2002b.

WISE, M. Saque. In: SHONDELL, D.; REYNAUD, C. (Eds.). A bíblia do treinador de voleibol. São Paulo: ArtMed, 2005. p.173-83.

ZANATTA, W.A.; SOUZA, J.C.; NASCIMENTO, J.V. Processo de seleção e treinamento de levantadores no voleibol catarinense infanto-juvenil masculino. Pensar a Prática, Goiânia, v.13, n.2, p.1-18, 2010. 


\section{Agradecimentos}

Agradecimento ao apoio financeiro da Coordenação de Aperfeiçoamento de Pessoal de Nível Superior (CNPq) e do Conselho Nacional de Desenvolvimento Científico e Tecnológico (Capes), dado para realização desta pesquisa, bem como para o aperfeiçoamento da estrutura de pesquisa científica, tecnológica e humana, do Centro de Estudos de Cognição e Ação (CECA), da Escola de Educação Física, Fisioterapia e Terapia Ocupacional (Universidade Federal de Minas Gerais).

Cristino Julio Alves da

Centro de Estudos de Cognição e Ação Escola de Educação Física, Fisioterapia e Terapia Ocupacional

Universidade Federal de Minas Gerais

Av. Antônio Carlos, 6627 - Pampulha

31270-901 - Belo Horizonte - MG - BRASIL e-mail: crismatias@gmail.com

Recebido para publicação: 12/ 05/ 2010

1a. Revisão: 04/01/2011

2a. Revisão: 30/05/2011

Aceito: 13/06/2011 